\title{
ULGA NA DZIAŁALNOŚĆ BADAWCZO-ROZWOJOWA JAKO SZANSA POPRAWY POZYCJI INNOWACYJNEJ POLSKICH PRZEDSIĘBIORSTW
}

\section{WSTĘP}

Pojęcia „innowacja” oraz „innowacyjność” stanowią jedno z najpopularniejszych haseł środowiska ekonomicznego, społecznego, a także biznesowego XXI w. Bezsprzecznie innowacyjność stanowi współcześnie kluczową determinantę konkurencyjności przedsiębiorstw oraz rozwoju gospodarczego państwa ${ }^{1}$. Współczesne warunki rynkowe charakteryzują się nieustannymi i dynamicznymi zmianami gospodarczymi oraz wysokim poziomem konkurencyjności. Przedsiębiorcy w celu utrzymania swojej pozycji rynkowej musza rozwijać się w tempie wykazywanym przez konkurencyjne przedsiębiorstwa, a w zasadzie nawet wyprzedzać poziom podyktowany przez inne podmioty. Rywalizacja podmiotów gospodarczych nie opiera się już wyłącznie na klasycznych formach konkurencji, jak cena i minimalizacja kosztu produkcji lub wykonania usługi. Kluczem pozycji rynkowej staje się różnorodnie interpretowana „innowacja”, która przekłada się m.in. na takie parametry prowadzonej działalności, jak: wzrost efektywności, wzrost mocy produkcyjnych lub wzrost jakości produktów i usług oferowanych przez innowatora na rynku².

Władze państw, dostrzegając istotę kreowania wartości dodanej poprzez innowacyjność, opracowują i wdrażają szereg form wsparcia i zachęt do podejmowania przez przedsiębiorstwa przedsięwzięć o charakterze badawczo-rozwojowym. Jedna z nich, oczekiwaną przez zainteresowane podmioty ${ }^{3}$, stanowią rozwiązania podatkowe w postaci m.in. ulg podatkowych. Również w Polsce w ostatnich latach podjęto szereg działań mających na celu wzrost innowacyjności przedsiębiorstw i poprawę ich niskich pozycji w międzynarodowych rankingach konkurencyjności i innowacyjności. Jedną z najpopularniejszych zmian w tym zakresie jest wprowadzenie do polskiego systemu podatkowego

1 A. Misztal, Otwarte innowacje w polskich przedsiębiorstwach - ewolucja, <yadda.icm.edu. pl/yadda/element/bwmeta1.element.desklight.../27-37_Misztal.pdf>, s. 28-29.

2 J. Sikora, A. Uziębło, Innowacja w przedsiębiorstwie - próba zdefiniowania, Wyd. UG, Gdańsk 2013, s. 351-352.

${ }^{3}$ P. Nowak, Preferencje podatkowe dla innowacyjnych przedsiębiorstw, „Prace Komisji Geografii Przemysłu Polskiego Towarzystwa Geograficznego” 2014, nr 28, s. 177. 
tzw. ulgi na działalność badawczo-rozwojowa jako podatkowego narzędzia aktywizacji w zakresie działalności $\mathrm{B}+\mathrm{R}$ przedsiębiorców.

\section{POJĘCIE INNOWACJI I DZIALALNOŚCI INNOWACYJNEJ}

Etymologicznie termin „innowacja” wywodzi się z łacińskiego słowa innovatio, które w tłumaczeniu dosłownym oznacza „odnowienie”. Powszechnie pojęcie to definiowane jest jako wprowadzenie czegoś nowego ${ }^{5}$. W literaturze i praktyce gospodarczej występują jednak bardzo różnorodne definicje słowa innowacja, co wynika z trudności jednoznacznej interpretacji i subiektywności w definiowaniu zagadnienia, „nowości”.

W literaturze naukowej najpopularniejszą definicją analizowanego pojęcia innowacji jest definicja wprowadzona przez Josepha Schumpetera. Austriacki ekonomista w pracy Teoria rozwoju gospodarczego sprowadził termin innowacja do wyszczególnienia pięciu przypadków ${ }^{6}$ :

- wytworzenie i wprowadzenie na rynek nowego towaru, który do tej pory nie był na rynku znany,

- zastosowania nowej metody/techniki produkcji, która nie była dotąd stosowana,

- pozyskania nowego rynku zbytu,

- zdobycia nowego źródła surowców lub półfabrykatów, niewykorzystywanych do tej pory do produkcji przez podmioty gospodarcze,

- nowej formy organizacyjnej produkcji

W XX w. powstawało wiele koncepcji interpretacyjnych innowacji, na podstawie których wyróżnia się kategorie koncepcji szerokich i wąskich. Pierwsze z nich skupiają się na wykreowaniu elementu „nowości” i rezultacie podjętych działań innowatora. Takie stanowisko w zakresie interpretacji przedmiotowego terminu przyjmował m.in. Christopher Freeman, który definiował to pojęcie jako wprowadzenie na rynek nowości produktowej, usługowej bądź też nowego sposobu zarządzania ${ }^{8}$. Podejście szerokie natomiast kładzie szczególny nacisk na element procesu i uwzględnia czynniki wpływające na istotę procesów tworzenia nowych rozwiązań. Podejście to reprezentowane jest m.in. przez cytowanego już Schumpetera ${ }^{9}$.

${ }^{4}$ M. Górka, Wybrane poglady na temat innowacji jako czynnika konkurencyjności podmiotów gospodarczych, Prace Naukowo-Dydaktyczne, Państwowa Wyższa Szkoła Zawodowa w Krośnie, z. 68 , Krosno 2015 , s. 31.

${ }^{5}$ Internetowy słownik PWN, <https://sjp.pwn.pl/szukaj/innowacja.html>.

${ }^{6}$ K. Kozioł-Nadolna, Modele zarzqdzania innowacjami w XXI wieku, Szczecin 2012, s. $295-296$.

${ }^{7}$ U. Zagóra-Jonszta, Teoria rozwoju gospodarczego i „twórczej destrukcji” Schumpetera oraz jej aktualność, 2015 <DOI:10.15290/ose.2015.03.75.02>, s. 23; A. Glapiński, Schumpeterowska teoria przedsiębiorcy, czyli skqd się bierze pies, Białystok 2015, s. 4-5.

8 A. Misztal, op. cit., s. 28-29 i cytowana tam literatura.

9 J. Sikora, A. Uziębło, op. cit., s. 354-355. 
Na przestrzeni lat różne poglądy na temat postrzegania innowacji i ewolucje jej zastosowań w praktyce gospodarczej prowadziły do wyodrębnienia dla danego okresu gospodarczego modeli innowacji. Chronologiczna kolejność występowania modeli innowacji przedstawiona została na schemacie 1.

\section{Schemat 1}

Rodzaje modeli innowacji w ujęciu chronologicznym

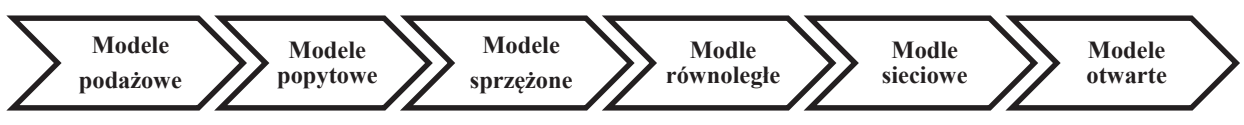

2010 r.

Źródło: opracowanie własne na podstawie A. Misztal, op. cit., s. 29-31.

Obecnie wykorzystywanym modelem innowacji jest tzw. koncepcja innowacji otwartych, której głównym założeniem jest kooperacja w zakresie prowadzenia działalności innowacyjnej między różnymi typami podmiotów funkcjonujacych na rynku. Wraz z ewolucją znaczenia innowacji i technologii teleinformatycznych wykorzystywanie wyłącznie badań prowadzonych przez przedsiębiorstwo we własnym zakresie do procesu tworzenia innowacji staje się nieefektywne. Za twórce modelu uważany jest Henry William Chesbrough, który po raz pierwszy przedstawił założenia modelu w literaturze przedmio$\mathrm{tu}^{10}$. Jego zdaniem podmiot dążący do innowacyjnych rozwiązań powinien wykorzystywać w tym celu wiedzę i rozwiązania wewnętrzne, czyli te wykreowane we własnym zakresie podmiotu, jak i zewnętrzne, wykreowane przez inne podmioty lub jednostki. Taki sposób procesu innowacyjnego prowadzi do znacznego jego usprawnienia, a także zwiększa szanse jego pozytywnego rezultatu ${ }^{11}$.

Źródłem nomenklatury związanej z innowacją i innowacyjnością są także tzw. międzynarodowe standardy metodologiczne. Tworzą one zestaw definicji pojęć oraz rekomendacji z zakresu metodologii badań statystycznych działalności badawczo-rozwojowej. Do zaleceń międzynarodowych standardów metodologicznych, takich jak Podręcznik Frascati i Podręcznik Oslo, stosuje się m.in. Główny Urząd Statystyczny w tworzonych analizach i raportach z zakresu przedmiotowej tematyki ${ }^{12}$.

Podręcznik Frascati (pełna nazwa: Proponowana standardowa praktyka badań statystycznych z zakresu działalności badawczej i prac rozwojowych) był pierwszym podręcznikiem określającym wytyczne badań statystycznych

${ }^{10}$ D. Rojek, Otwarte innowacje jako model interaktywnego zarzadzania innowacjami, „Administracja i Zarządzanie” 28, 2014, nr 101, s. 210-211.

${ }^{11}$ H.W. Chesbrough, Open Innovation: The New Imperative for Creating and Profiting from Technology, Boston, Mass., 2003, s. 41-45.

12 GUS, Nauka I technika w 2015 r., Informacje opracowania statystyczne, Warszawa 2016, s. 13 . 
nauki i techniki ${ }^{13}$. Działalność badawcza i rozwojowa definiowana jest w nim jako działania „obejmujace twórcze i systematyczne prace podjęte w celu zwiększenia zasobu wiedzy, w tym wiedzy o rodzaju ludzkim, kulturze i społeczeństwie, oraz opracowania nowego zastosowania dostępnej wiedzy"14. Podręcznik wyszczególnia trzy rodzaje prac:

- badania podstawowe (basic research) - prace teoretyczne i eksperymentalne nieukierunkowane na uzyskanie konkretnych zastosowań praktycznych,

- badania stosowane (applied research) - podjęte prace, których celem jest zdobycie nowej wiedzy o określonym zastosowaniu praktycznym,

- prace rozwojowe (experimental development) - prace polegajace na wykorzystaniu istniejącej wiedzy w celu opracowania nowych lub istotnego ulepszenia istniejących produktów, usług bądź procesów ${ }^{15}$.

Ze względu na znaczenie gospodarcze zagadnienie innowacji stało się przedmiotem prac OECD i zostało także zdefiniowane w tzw. Podręczniku Oslo. OECD definiuje innowację jako „wdrożenie nowego lub znaczaco udoskonalonego produktu (wyrobu lub usługi) lub procesu, nowej metody marketingowej lub nowej metody organizacyjnej w praktyce gospodarczej, organizacji miejsca pracy lub stosunkach z otoczeniem"16. Zgodnie z Podręcznikiem Oslo wyróżnia się cztery typy innowacyjności:

- innowacyjność produktowa, której rezultatem jest powstanie nowego produktu/ usługi,

- innowacyjność procesowa, której efektem jest ulepszenie metody produkcji, dystrybucji oraz wsparcie procesu świadczenia usług,

- innowacyjność marketingową polegająca na wykreowaniu nowej metody marketingowej rozumianej jako nowe rozwiązanie w zakresie wzornictwa i opakowania, metod sprzedaży wyrobów i usług, promocji i reklamy wyrobów i usług, metod ustalenia cen wyrobów i usług,

- innowacyjność organizacyjną polegająca na wdrożeniu nowego rozwiązania w zakresie praktyki biznesowej, miejsca pracy lub relacji ze środowiskiem zewnętrznym ${ }^{17}$.

W Podręczniku Oslo z 2005 r. OECD definiuje również pojęcie działalności innowacyjnej. Za działalność innowacyjną uważane są wszystkie działania posiadające charakter naukowy, techniczny, organizacyjny, finansowy i komercyjny, które z założenia mają lub prowadzą do wdrożenia innowacji. Przy czym podejmowane działania mają charakter innowacyjny lub jedynie stanowia niezbędny element do wdrożenia „nowości” spełniającej kryteria innowacji. Przykładem działań prowadzących do wdrożenia innowacji są prace badawczo-roz-

${ }^{13}$ Portal Innowacji, <http://www.pi.gov.pl/PARP/chapter_96055.asp?soid=D49A720F3C72491 E90F0EF057232EC14>.

${ }_{14}$ OECD, Frascati Manual 2015. Guidelines for collecting and reporting data on research and experimental development, Paris 2015, s. 44.

${ }^{15}$ Ibidem, s. 45.

${ }^{16}$ OECD, Guidelines for Collecting and Interpreting Innovation Data, Oslo Manual, 2005, s. 46 .

${ }^{17}$ Ibidem, s. 47-50. 
wojowe (dalej: prace $\mathrm{B}+\mathrm{R}$ ). Nie stanowią one innowacji sensu stricto, ale ich pozytywne rezultaty moga prowadzić do powstania innowacji.

W literaturze przedmiotu występują głównie dwa sposoby interpretacji innowacyjności przedsiębiorstwa. Pierwsze z nich wskazuje, aby innowacyjność przedsiębiorstw postrzegać jako synonim innowacji. Dominującym poglądem jest jednak pojmowanie tego zagadnienia nie jako stricte innowacji, ale zdolności do wdrożenia innowacji ${ }^{18}$. Na potrzeby niniejszego artykułu wykorzystywana będzie druga z przedstawionych interpretacji tego pojęcia.

\section{POZIOM INNOWACYJNOŚCI POLSKICH PRZEDSIĘBIORSTW NA TLE PAŃSTW UNII EUROPEJSKIEJ}

Innowacyjność przedsiębiorstw uznawana jest za jedną z najistotniejszych determinant rozwoju gospodarczego państw ${ }^{19}$, a także całej Unii Europejskiej w XXI w. Wzrost poziomu innowacyjności przedsiębiorstw wiąże się bowiem co do zasady z:

- wzrostem konkurencyjności gospodarki kraju na arenie międzynarodowej,

- atrakcyjnością dla inwestorów,

- tworzeniem nowych miejsc pracy,

- poprawą warunków bytu obywateli ${ }^{20}$.

Poziom innowacyjności polskich przedsiębiorstw relatywnie do wyników przedsiębiorstw innych państw UE od lat kształtuje się na niskim poziomie. Świadczą o tym m.in. wielkości takich wskaźników ekonomicznych, jak Sumaryczny Indeks Innowacyjności czy wielkość nakładów na działalność B+R. Wymienione mierniki zasadniczo określają poziom innowacyjności państw i pozwalają na porównanie ich pozycji na tle pozostałych krajów UE. Jednakże główną składową ostatecznego wyniku wskazanych mierników są wyniki osiągane przez przedsiębiorców, przez co pośrednio można uznać je także za miarę innowacyjności przedsiębiorstw poszczególnych państw.

Sumaryczny Indeks Innowacyjności (SII) to złożony wskaźnik przeznaczony do pomiaru innowacyjności krajów Unii Europejskiej. Ostateczny wynik wskaźnika SII kalkulowany jest na podstawie algorytmu 25 wskaźników czastkowych. Ustalenie poziomu SII pozwala na sklasyfikowanie danego państwa jako członka jednej z IV grup:

Grupa I - do tej grupy należą tzw. liderzy innowacyjności, czyli państwa członkowskie, których wielkość wskaźnika w istotny sposób przewyższyła średnią SII wyznaczonego dla UE28.

${ }^{18}$ T. Kraśnicka, Innowacyjność przedsiębiorstw - uwarunkowania organizacyjne, „Studia Ekonomiczne" 2013, s. 167.

${ }^{19}$ J. Prystrom, Innowacyjność a konkurencyjność gospodarki Luksemburga, Prace Naukowe Uniwersytetu Ekonomicznego we Wrocławiu 41, Wrocław 2015, s. 400-401.

${ }^{20}$ Ibidem, s. 403. 
Grupa II - to tzw. zaawansowani innowatorzy, czyli kraje, których poziom wskaźnika SII jest zbliżony do wskaźnika UE28.

Grupa III - określana mianem umiarkowanych innowatorów. Zaliczane są do niej kraje, dla których wskaźnik osiaga wielkość niższą od średniej UE28.

Grupa IV - grupa krajów charakteryzująca się najniższym poziomem SII na tle państw wspólnoty ${ }^{21}$.

Wielkość wskaźnika SII w 2016 r. dla Polski wyniosła 54,8\%, co klasyfikuje Polskę w rankingu opartym na wskaźniku SII na 25 z 28 pozycji. Osiagnięty wynik pozycjonuje Polskę w przedostatniej z wyznaczonych grup - umiarkowanych inwestorów. Różnica między wartością SII Polski a SII UE28 (102\%) jest znacząca i wynosi 47,2 punktu procentowego. Niższy wynik SII niż Polska uzyskały jedynie Rumunia i Bułgaria, które jako jedyne kraje zostały zaliczone do grupy skromnych inwestorów. Nieznacznie niższy od Polski, gdyż zaledwie o 0,1 punktu procentowego, wynik osiąnęła także Chorwacja.

Liderami rankingu sa takie kraje, jak: Szwecja, Dania, Finlandia, Holandia, Wielka Brytania i Niemcy. Poziom osiagniętego przez wskazane kraje wskaźnika znajduje się w przedziale od 123,4\% do 143,6\%. Wielkości te sa niemal dwukrotnie wyższe od wyniku SII dla Polski.

Indywidualna analiza poziomu wskaźnika SII uzyskiwanego przez Polskę $\mathrm{w}$ oderwaniu od zestawienia z wynikami innych krajów pozwala na wysnucie bardziej pozytywnych wniosków. Wielkości wskaźnika SII osiagane przez Polskę w latach 2010-2016 przedstawiono na wykresie 1.

\section{Wykres 1}

Wartość Sumarycznego Indeksu Innowacyjności dla Polski w latach 2010-2016 (w \%, EU28 $2010=100 \%$ )

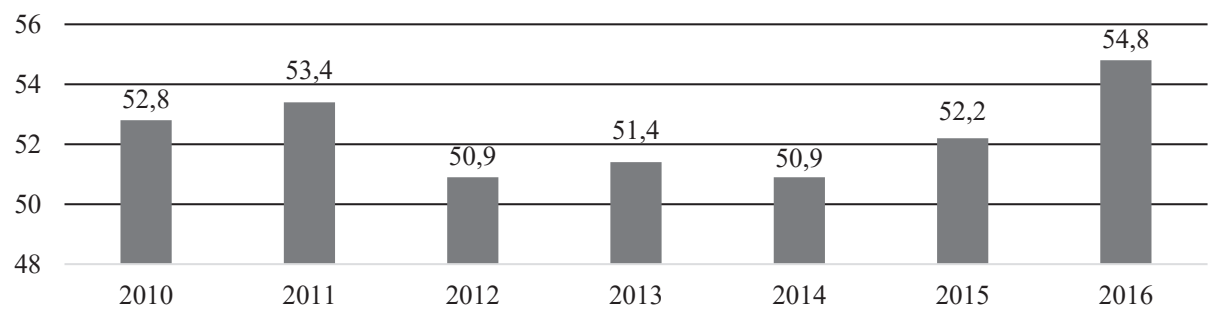

Źródło: opracowanie własne na podstawie <http://ec.europa.eu/growth/industry/innovation/facts-figures/ scoreboards_en>.

W analizowanym okresie wartość SII dla Polski nie zmieniła się istotnie - w latach 2010-2016 wzrost na poziomie zaledwie 2 punktów procentowych Należy jednak zauważyć, że wskaźnik SII na koniec badanego okresu osiagnął

${ }^{21}$ B. Mikołajczyk, Mierniki monitorowania innowacyjności w skali makro $w$ krajach Unii Europejskiej, Studia Ekonomiczne, t. 186, cz. 1, Wyd. UE w Katowicach, Katowice 2014, s. 286287. 
wartość najwyższą $(54,8 \%)$ w stosunku do lat pozostałych. Dodatkowo w latach 2014-2016 zauważalna jest wyraźna tendencja wzrostowa wielkości analizowanego wskaźnika. Wielkość SII wzrastała bowiem w okresie ostatnich trzech lat sukcesywnie z poziomu 50,9\% w 2014 do poziomu 52,2\% w 2015, a w 2016 r. do poziomu 54,8\%.

Znacznie korzystniejsze dla Polski wartości przyjmuje kolejny ze wskaźników innowacyjności, jakim jest wielkość nakładów poniesionych na działalność $\mathrm{B}+\mathrm{R}$. Wielkość nakładów na $\mathrm{B}+\mathrm{R}$ poniesionych przez wybrane państwa UE w 2016 r. przedstawiono w tabeli 1.

W 2016 r. wydatki państw członkowskich UE na działalność badawczo-rozwojową wyniosły łącznie ponad 302 mld EUR, co stanowi 2,03\% PKB UE. W ujęciu nominalnym najwyższy poziom wydatków na działalność badawczo-rozwojową poniosły Niemcy - 92419 mln EUR, co stanowiło 2,49\% PKB gospodarki Niemiec. Najwyższy poziom wydatków w relacji do PKB odnotowano w przypadku Szwecji, gdzie przedmiotowe nakłady stanowiły 3\% PKB.

\section{Tabela 1}

Nakłady na działalność badawczo-rozwojową w 2016 r. wybranych państw Unii Europejskiej

\begin{tabular}{|l|c|c|c|}
\hline Wyszczególnienie & EUR (mln) & \% PKB & $\begin{array}{c}\text { Udział przedsiębiorstw } \\
\text { w nakładach B+R (\%) }\end{array}$ \\
\hline Belgia & 10518 & 2,49 & 70 \\
\hline Czechy & 2963 & 1,68 & 61 \\
\hline Niemcy & 92419 & 2,94 & 68 \\
\hline Polska & 4112 & 0,97 & 66 \\
\hline Finlandia & 5926 & 2,75 & 70 \\
\hline Szwecja & 15141 & 3,25 & 67 \\
\hline Wielka Brytania & 40451 & 1,69 & 66 \\
\hline
\end{tabular}

Źródło: opracowanie własne na podstawie <http://ec.europa.eu/eurostat/documents/2995521/8493770/ 9-01122017-AP-EN.pdf/94cc03d5-693b-4c1d-b5ca-8d32703591e7>.

Polska pod względem relacji wydatków na działalność B+R zajmuje 2 pozycję na tle innych państw UE. Natomiast poziom nominalny przedmiotowych wydatków na tle wyników państw UE, klasyfikuje Polskę na znaczenie wyższej - 12 pozycji wśród krajów UE. Niemniej jednak obie wielkości, zarówno nominalna, jak i wyrażona w procencie PKB, znajdują się znacznie poniżej wyników osiagniętych przez UE. Średnia nominalna wydatków wyniosła bowiem 10 793,57 mln EUR, natomiast relacja wydatków do PKB dla UE, jak już wcześniej wspomniano, wyniosła 2,03\%.

Dodatkowo należy podkreślić, że we wszystkich krajach UE przedsiębiorstwa posiadały największy udział w łącznej wielkości wewnętrznych nakładów na działalność badawczo-rozwojową. W Polsce udział przedsiębiorstw w nakładach wewnętrznych na działalność B+R w 2016 r. kształtował się 
na poziomie blisko $66 \%$, co oznacza wzrost tej wielkości o ok. 19,4 punktu procentowego w stosunku do 2015 r. $(46,6 \%)^{22}$. Przyczyny tak wysokiego wzrostu udziału sektora przedsiębiorstw można upatrywać m.in. w wykorzystaniu przez przedsiębiorców środków unijnych dostępnych w ramach programów zarówno poprzedniej perspektywy 2007-2013, jak i bieżącej perspektywy 2014-2020.

W celu przedstawienia pełnego obrazu aspektu innowacyjności Polski mierzonej za pomocą wielkości nakładów na działalność $\mathrm{B}+\mathrm{R}$ należy również poddać analizie kierunek zmian tej wielkości w ostatnich latach. Wielkość nakładów wewnętrznych na działalność B+R w Polsce w latach 2012-2016 przedstawiono w tabeli 2 .

Tabela 2

Wielkość nakładów wewnętrznych na działalność B+R w Polsce w latach 2012-2016 wyrażona w mln zł oraz jako \% PKB

\begin{tabular}{|l|c|c|c|c|c|}
\hline \multicolumn{1}{|c|}{ Wyszczególnienie } & $\mathbf{2 0 1 2}$ & $\mathbf{2 0 1 3}$ & $\mathbf{2 0 1 4}$ & $\mathbf{2 0 1 5}$ & $\mathbf{2 0 1 6}$ \\
\hline $\begin{array}{l}\text { Nakłady wewnętrzne na badania } \\
\text { i prace rozwojowe (w mln zł) }\end{array}$ & 14353 & 14424 & 16168 & 18061 & 17943 \\
\hline $\begin{array}{l}\text { Relacja nakładów wewnętrznych } \\
\text { na B+R do PKB (w \%) }\end{array}$ & 0,88 & 0,87 & 0,94 & 1,0 & 0,97 \\
\hline
\end{tabular}

Źródło: GUS, Działalność badawcza i rozwojowa w 2016 r., Warszawa 2017, s. 1.

$\mathrm{Na}$ podstawie analizy danych zawartych w tabeli 2 należy stwierdzić, że w latach 2012-2015 wielkości nakładów na badania i rozwój towarzyszyła tendencja wzrostowa. Wyjątek od tendencji wzrostowej stanowił ostatni rok badanego okresu, w którym odnotowano spadek analizowanej wielkości na poziomie $118 \mathrm{mln}$ zł, co przełożyło się także na spadek w relacji do PKB o 3 punkty procentowe. Ostatecznie jednak należy zauważyć, że poziom wydatków w badanym okresie wzrósł z poziomu $14353 \mathrm{mln}$ zł i 0,88\% PKB w 2012 do poziomu $17943 \mathrm{mln}$ zł i 0,97\% PKB w 2016 r.

Podsumowujac, pozycja innowacyjności Polski mierzona Sumarycznym Indeksem Innowacyjności jest bardzo niska, ponieważ Polska zajmuje jedno z ostatnich miejsc wśród państw UE pod względem jego wielkości. Znacznie korzystniej kształtuje się pozycja Polski na tle państw UE pod względem wydatków na działalność badawczo-rozwojowa - w ujęciu nominalnym plasuje się na 12 pozycji. Zarówno wielkość wskaźnika SII oraz wysokość nakładów na działalność B+R w Polsce w 2016 r. znajdowała się poniżej wielkości średnich dla UE.

Analizując jednak kierunek zmian wielkości wskazanych wskaźników, należy zauważyć, że obie wielkości na przestrzeni ostatnich kilku lat charakteryzowały się tendencją wzrostową. Innowacyjność Polski na tle państw UE

${ }^{22}$ GUS, Działalność badawcza i rozwojowa w Polsce w 2015 r., Warszawa 2016, s. 1 i 2. 
należy określić jako niska, pozytywny kierunek zmian SII oraz wydatków na działalność B+R należy jednak interpretować jako pozytywną przesłankę poprawy pozycji Polski w rankingu krajów UE w kolejnych latach.

Lata 2014-2016, w których odnotowano zmiany o kierunku pozytywnym wskaźników określających poziom innowacyjności Polski, pokrywaja się z okresem rozpoczęcia programów nowej perspektywy pozyskania funduszy unijnych 2014-2020, których głównym celem jest wzrost innowacyjności przedsiębiorstw. We wskazanym okresie wprowadzono również istotne zmiany legislacyjne w zakresie zniesienia barier podejmowania działalności innowacyjnej przez przedsiębiorców, w tym także barier w podejmowaniu i prowadzeniu działalności badawczo-rozwojowej.

Jedną z najpopularniejszych regulacji prawnych, która wdrożyła do systemu nowe narzędzia wsparcia innowacyjności przedsiębiorców, była ustawa z 25 września 2015 r. o zmianie niektórych ustaw w związu ze wspieraniem innowacyjności. Ustawa ta wprowadziła do podatku dochodowego od osób fizycznych $^{23}$ oraz podatku dochodowego od osób prawnych ${ }^{24}$ nową preferencję podatkowa, która nazywana jest „ulga na działalność badawczo-rozwojowa” lub „ulga B+R”.

\section{ULGA B+R JAKO NARZĘDZIE WSPIERAJĄCE PODEJMOWANIE INNOWACYJNYCH DZIALAŃ PRZEDSIĘBIORSTWA}

Struktura wsparcia działalności innowacyjnej polskich przedsiębiorstw opierała się do 2015 r. w głównej mierze na pozyskaniu środków pochodzących z funduszy unijnych - dotacje na działania B+R przedsiębiorców ${ }^{25}$. Pomoc UE $\mathrm{w}$ tym aspekcie udzielana była również w formie zwrotnej w postaci pożyczek oraz poręczeń na warunkach korzystniejszych od rynkowych. Pozostałe formy wsparcia, jak np. przewidziane w ówczesnym stanie prawnym preferencje podatkowe, miały w strukturze wsparcia polskiej innowacyjności znaczenie marginalne. Od ok. 2015 r. pojęcie innowacyjności stało się zagadnieniem często poruszanym przez polskie władze, które deklarują jej wspieranie jako jeden z priorytetów prowadzonej aktualnie polityki ${ }^{26}$.

Jednym z celów Polski, związanym z realizacją Strategii Europa 2020, jest wzrost nakładów inwestycyjnych łącznie do poziomu 1,7\% PKB w $2020 \mathrm{r}$. Dla porównania w 2015 r. nakłady wewnętrzne na działalność B+R stanowiły

${ }^{23}$ Ustawa z 26 lipca 1991 r. o podatku dochodowym od osób fizycznych, t.jedn.: Dz. U. 2015, poz. 1767 (dalej jako: u.p.d.o.f.).

${ }^{24}$ Ustawa z 15 lutego 1992 r. o podatku dochodowym od osób prawnych (t.jedn.: Dz. U. 2015, poz. 1767 (dalej jako: u.p.d.o.p.).

${ }^{25}$ Uzasadnienie ustawy o zmianie niektórych ustaw w związku ze wspieraniem innowacyjności, s. 7.

${ }_{26}$ Zob. <http://www.pap.pl/aktualnosci/debaty/news,466191,kwiecinski-innowacje-jednym-zpriorytetow-polityki-rozwoju-rzadu.html>. 
1\% PKB, z czego sektor przedsiębiorstw odpowiadał za 46,6\% tej wielkości ${ }^{27}$. Wyznaczony cel oznacza konieczność zwiększenia poziomu innowacyjności i wzmożonych działań z zakresu B+R polskich przedsiębiorców.

Dostrzeżono, że obecny model wspierania działalności innowacyjnej wymaga gruntownej zmiany. Po pierwsze, polskie przedsiębiorstwa od lat charakteryzuja się niskim poziomem innowacyjności, co świadczy o nieefektywności dotychczasowego modelu. Po drugie, zauważona została szansa lepszego wykorzystania środków dostępnych w ramach perspektywy 2014-2020 przy zastosowaniu innych narzędzi wsparcia. Po trzecie, po zakończeniu obecnej perspektywy 2014-2020 fundusze UE zostana znacznie ograniczone, co oznacza konieczność zmiany dotychczasowego modelu opartego właśnie na środkach UE - na model bazujący w dominującym stopniu na innych rozwiąaniach.

Jedna z pierwszych zmian wprowadzonych w ramach aktywizacji działalności $\mathrm{B}+\mathrm{R}$ przedsiębiorstw i pierwszym krokiem w stronę przebudowy modelu wsparcia działalności innowacyjnej przedsiębiorstw w Polsce było wprowadzenie do systemu podatków dochodowych tzw. ulgi na działalność badawczo-rozwojowa. Ulga $\mathrm{B}+\mathrm{R}$ zastapiła funkcjonującą $\mathrm{w}$ ówczesnym stanie prawnym ulgę na nabycie nowych technologii, która uznana została za narzędzie nieefektywne w zakresie wsparcia podejmowania działalności B+R. Ulga na nabycie nowych technologii funkcjonowała od 2006 r. i zakładała możliwość odliczenia od podstawy opodatkowania 50\% wydatków poniesionych na ten cel. Skorzystanie jednak z tej możliwości ograniczone było licznymi warunkami, m.in.:

- nabyta technologia musiała spełniać kryterium „nowej”, tzn. nie mogła być używana przez okres 5 ostatnich lat na świecie,

- powyższe kryterium było spełnione tylko w przypadku posiadania przez podatnika potwierdzenia w postaci opinii niezależnej jednostki naukowej,

- nowa technologia musiała umożliwiać wytwarzanie lub istotne ulepszenie nowych produktów lub usług,

- z ulgi nie mógł skorzystać podatnik prowadzący w roku podatkowym poprzedzającym lub roku podatkowym nabycia nowej technologii działalność na terenie specjalnej strefy ekonomicznej,

- z podstawy ustalenia kwoty odliczenia wykluczono wydatki, które zostały zwrócone podatnikowi w jakiejkolwiek formie (np. dotacji),

- odliczenia można było dokonać w okresie 3 kolejnych lat podatkowych od roku, w którym wprowadzono technologię do ewidencji środków trwałych,

- wyłączona została możliwość udzielenia praw z nabytej technologii innym podmiotom w okresie 3 lat od jej nabycia ${ }^{28}$.

Powyższe kryteria należy określić mianem dość rygorystycznych i ciężkich do spełnienia przez większość podatników ${ }^{29}$. Liczbę podatników oraz kwoty odliczeń w ramach ulgi na nabycie nowych technologii w latach 2011-2015 przedstawiono w tabeli 3.

27 GUS, Działalność badawcza i rozwojowa w Polsce w 2015 r., Warszawa 2016, s. 1.

28 Art. 18c u.p.d.o.p. oraz art. 26 u.p.d.o.f. (stan prawny na 2015 r.).

29 Uzasadnienie ustawy..., s. 6. 
Tabela 3

Liczba podatników oraz kwota odliczeń ulgi technologicznej

przez przedsiębiorstwa z podziałem na u.p.d.o.f. oraz u.p.d.o.p. w latach 2011-2015

\begin{tabular}{|c|c|c|c|c|}
\hline \multicolumn{2}{|c|}{$\begin{array}{c}\text { Wyszczególnie- } \\
\text { nie }\end{array}$} & \multirow{2}{*}{$\begin{array}{c}\text { Liczba podatników } \\
250 \\
\end{array}$} & \multirow{2}{*}{$\begin{array}{c}\text { Kwota odliczenia } \\
\text { (w tys. PLN) }\end{array}$} & \multirow{2}{*}{$\begin{array}{l}\text { Wysokość przeciętnego } \\
\text { odliczenia (w tys. PLN) } \\
1,05\end{array}$} \\
\hline \multirow{3}{*}{2011} & u.p.d.o.f. & & & \\
\hline & u.p.d.o.p. & 87 & 237011 & 2724,26 \\
\hline & Ogólem & 337 & 237273 & 704,07 \\
\hline \multirow{3}{*}{2012} & u.p.d.o.f. & 42 & 140 & 3,33 \\
\hline & u.p.d.o.p. & 77 & 309080 & 4014,03 \\
\hline & Ogólem & 119 & 309220 & 2598,49 \\
\hline \multirow{3}{*}{2013} & u.p.d.o.f. & 31 & 885 & 28,55 \\
\hline & u.p.d.o.p. & 55 & 223948 & 4071,78 \\
\hline & Ogółem & 86 & 224833 & 2614,34 \\
\hline \multirow{3}{*}{2014} & u.p.d.o.f. & 37 & 754 & 20,34 \\
\hline & u.p.d.o.p. & 60 & 219869 & 3664,48 \\
\hline & Ogólem & 97 & 220623 & 2274,46 \\
\hline \multirow{3}{*}{2015} & u.p.d.o.f. & 472 & 779 & 1,66 \\
\hline & u.p.d.o.p. & 66 & 334313 & 5065,35 \\
\hline & Ogółem & 538 & 335092 & 622,85 \\
\hline
\end{tabular}

Źródło: opracowanie własne na podstawie Informacji dotyczących rozliczenia podatku dochodowego od osób fizycznych za lata 2011-2015 oraz Informacji dotyczących rozliczenia podatku dochodowego od osób prawnych za lata 2011-2015, Ministerstwo Finansów, 2011-2015, <www.finanse.mf.gov.pl>.

Na podstawie analizy danych zawartych w tabeli 3 należy stwierdzić, że podatnicy u.p.d.o.p. pod względem wielkości odliczeń byli głównymi beneficjentami ulgi na nabycie nowych technologii. Liczniejsza grupa korzystających z ulgi stanowili z kolei podatnicy u.p.d.o.f. Przeciętna wysokość odliczenia podatników u.p.d.o.f. była nieporównywalnie niższa niż przeciętna wysokość odliczeń podatników u.p.d.o.p.

Głównym mankamentem ulgi na nabycie nowych technologii był mechanizm zachęcający do samego zakupu nowych technologii, a nie do podejmowania działań własnych przedsiębiorstw w zakresie wytwarzania i prac nad ich opracowywaniem. W efekcie ulga ta przyczyniała się do importu nowych technologii z zagranicy, a nie do kreowania innowacji wewnątrz kraju. Dodatkowo ulga na nabycie nowych technologii miała zastosowanie wyłącznie do nabycia środków trwałych i nie pozwalała na odliczenie nabycia wartości niematerialnych i prawnych. Ze względu na wskazane wady ulga ta uznana została za nieefektywną w zakresie wpływu na poprawę poziomu innowacyjnego przedsiębiorstw ${ }^{30}$.

30 Ibidem. 
Dostrzegajac mankamenty ulgi na nabycie nowych technologii, zastapiono ją nową ulgą na działalność badawczo-rozwojową. Podstawowe różnice między analizowanymi ulgami zestawiono w tabeli 4.

\section{Tabela 4}

Podstawowe różnice między ulgą na nabycie nowych technologii a ulgą na działalność badawczo-rozwojowa

\begin{tabular}{|l|l|l|}
\hline \multicolumn{1}{|c|}{ Wyszczególnienie } & Ulga na nowe technologie & $\begin{array}{c}\text { Ulga na działalność } \\
\text { badawczo-rozwojową } \\
\text { (stan na 2016 r.) }\end{array}$ \\
\hline Istota & nabycie nowych technologii & $\begin{array}{l}\text { prowadzenie działalności } \\
\text { B+R } \\
\text { współpraca } \\
\text { przedsiębiorstw } \\
\text { z jednostkami naukowymi }\end{array}$ \\
\hline $\begin{array}{l}\text { Kwota do odliczenia } \\
\text { Efekt działań }\end{array}$ & $\begin{array}{l}\text { kwota wydatków } \\
\text { poniesionych na nabycie } \\
\text { nowej technologii }\end{array}$ & $\begin{array}{l}\text { koszty kwalifikowane do } \\
\text { kwoty ustalonego limitu }\end{array}$ \\
\hline $\begin{array}{l}\text { Uzależnienie intensywności } \\
\text { preferencji podatkowej od } \\
\text { wielkości przedsiębiorstwa }\end{array}$ & tak & nie \\
\hline $\begin{array}{l}\text { Ograniczenie sposobów } \\
\text { komercjalizacji }\end{array}$ & nomie \\
\hline $\begin{array}{l}\text { Możliwość skorzystania przez } \\
\text { podatnika opodatkowanego } \\
\text { według stawki liniowej }\end{array}$ & tak & tak \\
\hline
\end{tabular}

Źródło: opracowanie własne na podstawie porównania zmiany stanu prawnego u.p.d.o.p. oraz ustawy o u.p.d.o.f. (stan prawny na 2016 i 2017 r.).

Celem wprowadzenia nowej ulgi była poprawa warunków rozwoju działalności innowacyjnej, zwłaszcza w sektorze prywatnym przedsiębiorstw, oraz wzmocnienie współpracy między jednostkami naukowymi i przedsiębiorstwami. Drugie z założeń świadczy o inicjatywie wykorzystania przez ustawodawcę modeli innowacji otwartych, które uważane sa za znacznie bardziej efektywne. Zakładaja one bowiem wykorzystywanie przez przedsiębiorców wiedzy zewnętrznych podmiotów. Przejawem współpracy jednostek zewnętrznych i przedsiębiorstw w ramach ulgi $\mathrm{B}+\mathrm{R}$ jest m.in. konieczność zawarcia umowy lub porozumienia z jednostką naukową w zakresie badań podstawowych ${ }^{31}$. Badania te definiowane sa jako: ,oryginalne prace badawcze, eksperymentalne lub teoretyczne podejmowane przede wszystkim w celu zdobywania nowej wiedzy o podstawach zjawisk i obserwowalnych faktów bez nastawienia na bezpośrednie zastosowanie komercyjne" ${ }^{32}$.

${ }^{31}$ Art. $18 d$ ust. 4 u.p.d.o.p. oraz art. 26 ust. 4 u.p.d.o.f.

${ }^{32}$ Art. $5 a$ ust. 39 lit. a u.p.d.o.p. oraz art. 5 a ust. 39 lit. a u.p.d.o.f. 
Nowo wprowadzona w 2016 r. ulga zakłada odliczenie od podstawy opodatkowania ograniczonej kwoty wydatków poniesionych na działalność badawczo-rozwojowa. Rodzaje odliczanych wydatków nazywane sa „kosztami kwalifikowanymi” bez względu na to, czy koszty te zostały już zliczone do kosztów uzyskania przychodu. Zakres kosztów kwalifikowanych został wskazany w art. 18 d ust. 2 i 3 u.p.d.o.p. oraz art. 26 e ust. 2 i 3 u.p.d.o.f., $\mathrm{w}$ których wyszczególniono m.in. wydatki podatnika poniesione $\mathrm{w}$ związku z działalnością $B+R$, na:

a) wynagrodzenia pracowników zatrudnionych w celu realizacji działalności badawczo-rozwojowej oraz składki na ubezpieczenia społeczne,

b) nabycie materiałów i surowców bezpośrednio związanych z prowadzoną działalnością badawczo-rozwojowa,

c) ekspertyzy, opinie, usługi doradcze oraz usługi równorzędne, a także nabycie wyników badań naukowych, świadczonych lub wykonywanych na podstawie umowy przez jednostkę naukową na potrzeby prowadzonej działalności badawczo-rozwojowej,

d) odpłatne korzystanie z aparatury naukowo-badawczej wykorzystywanej wyłacznie w prowadzonej działalności badawczo-rozwojowej, pod warunkiem że aparatura nie jest wykorzystywana przez przedsiębiorcę na podstawie umowy zawartej z podmiotem powiazanym w rozumieniu prawa podatkowego.

Możliwa wysokość odliczenia wyszczególnionych w ustawach u.p.d.o.f. i u.p.d.o.p. uzależniona została od wielkości przedsiębiorstwa. Wielkość limitów odliczeń kosztów kwalifikowanych została przedstawiona na wykresie 2.

\section{Wykres 2}

Wielkość limitów odliczeń kosztów kwalifikowanych w ramach ulgi badawczo-rozwojowej w 2016 r.

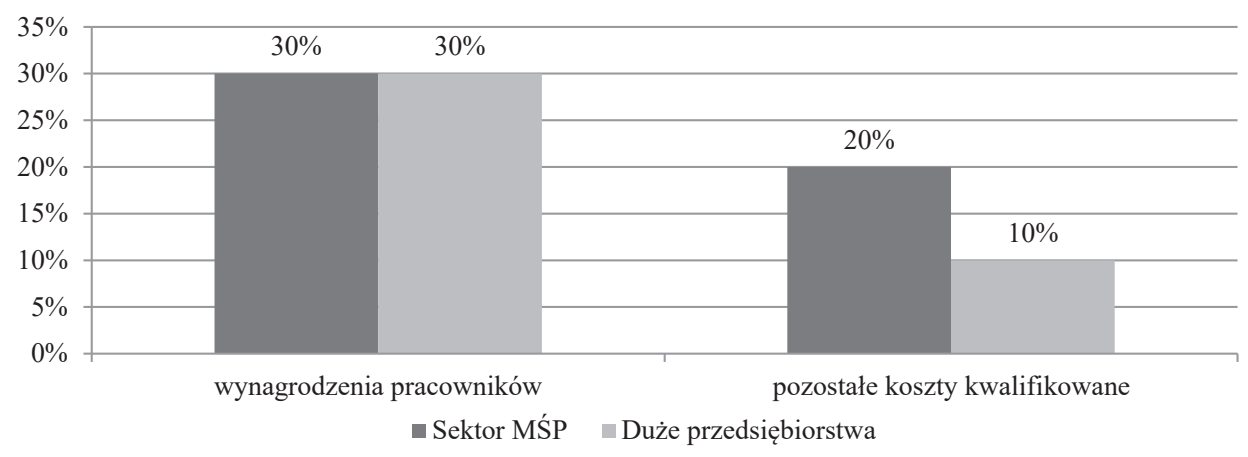

Źródło: opracowanie własne na podstawie art. 18 ust. 7 u.p.d.o.p. oraz art. 26 e ust. 7 u.p.d.o.f. (stan prawny na 2016 r.).

Limit kosztów kwalifikowanych z tytułu wynagrodzeń ustalony został na poziomie $30 \%$ bez rozróżnienia na wielkość przedsiębiorstwa. Wysokość możliwych kwot odliczeń pozostałych kosztów kwalifikowanych została określona dla sektora mikro-, małych i średnich przedsiębiorstw na poziomie o 10 punktów procentowych wyższym niż dla przedsiębiorstw dużych. W praktyce oznacza to 
obniżenie kosztów działalności badawczo-rozwojowej sektora MŚP o wysokość podatku od równowartości tej różnicy punktów procentowych.

Pierwszym rokiem podatkowym, za który podatnikom przysługiwało rozliczenie ulgi B+R, był 2016 r. Liczbę i kwotę odliczeń w ramach ulgi B+R przez podatników u.p.d.o.f. oraz u.p.d.o.p. przedstawiono w tabeli 5.

W przeciwieństwie do danych dotyczacych rozliczeń ulgi na nowe technologie (tab. 3), dane za pierwszy rok podatkowy funkcjonowania ulgi $B+R$ nie wykazują dysproporcji w liczbie podatników u.p.d.o.p. oraz u.p.d.o.f. korzystających z preferencji podatkowej. Zarówno w u.p.d.o.p., jak i u.p.d.o.f. z ulgi skorzystało 264 podatników. Widoczne jest także zmniejszenie rozbieżności pomiędzy przeciętną wysokością odliczenia w u.p.d.o.p. a u.p.d.o.f., które nadal pozostaje na istotnie wysokim poziomie.

Tabela 5

Liczba i kwota odliczenia ulgi badawczo-rozwojowej w 2016 r.

\begin{tabular}{|l|l|c|c|c|}
\hline \multicolumn{2}{|c|}{ Wyszczególnienie } & $\begin{array}{c}\text { Liczba } \\
\text { podatników }\end{array}$ & $\begin{array}{c}\text { Kwota } \\
\text { odliczenia } \\
\text { (w tys. PLN) }\end{array}$ & $\begin{array}{c}\text { Przeciętne } \\
\text { odliczenie } \\
\text { (w tys. PLN) }\end{array}$ \\
\hline \multirow{2}{*}{ u.p.d.o.p. } & skala podatkowa & $\mathbf{2 6 4}$ & $\mathbf{1 9 8 3 3 4}$ & $\mathbf{7 5 1 , 0 0}$ \\
\hline \multirow{3}{*}{ u.p.d.o.f. } & podatek liniowy & 168 & 390 & 4,06 \\
\cline { 2 - 5 } & Razem: & $\mathbf{2 6 4}$ & 7332 & 43,64 \\
\hline Ogółem: & & $\mathbf{5 2 8}$ & $\mathbf{7 7 2 2}$ & $\mathbf{2 9 , 2 5}$ \\
\hline
\end{tabular}

Źródło: opracowanie własne na podstawie Informacji dotyczących rozliczenia podatku dochodowego od osób fizycznych za lata 2011-2015 oraz Informacji dotyczących rozliczenia podatku dochodowego od osób prawnych za lata 2011-2015, Ministerstwo Finansów, 2011-2015, <www.finanse.mf.gov.pl>.

Zasady korzystania i zakres ulgi B+R był na przestrzeni lat 2016-2018 znacząco dla przedsiębiorców modyfikowane przez ustawodawcę. Zakres najważniejszych zmian w tym okresie przedstawiono w tabeli 6 .

Analizując wyszczególnione zmiany w stanie prawnym, należy wskazać, że z roku na rok forma ulgi na działalność badawczo-rozwojową stawała się dla przedsiębiorców bardziej atrakcyjna. Jako najważniejszą zmianę w badanym okresie należy wskazać wzrost poziomu limitu odliczeń koszów kwalifikowanych. W 2017 r. znacząco wzrósł poziom limitu odliczenia każdej kategorii kosztów kwalifikowanych o 20 punktów procentowych w stosunku do maksymalnej wielkości odliczeń określonych w roku poprzednim. Zmiana ta odnosiła się do limitu wyznaczonego zarówno dla sektora MŚP, jak i dużych przedsiębiorstw.

W 2018 r. zmienione zostało kryterium warunkujące wysokość limitu. Kryterium wielkości przedsiębiorstwa zastapione zostało kryterium posiadania przez przedsiębiorstwo statusu centrum badawczo-rozwojowego. Nie nale- 
ży jednak charakteru tej modyfikacji oceniać negatywnie dla przedsiębiorstw sektora MŚP. Wraz ze zmianą założenia nastapiła bowiem również zmiana wysokości możliwych odliczeń do $150 \%$ dla przedsiębiorstw posiadajacych status centrum badawczo-rozwojowego oraz 100\% kosztów kwalifikowanych dla pozostałych przedsiębiorstw. Dodatkowo rozszerzono i doprecyzowano katalog kosztów kwalifikowanych.

\section{Tabela 6}

Zestawienie najistotniejszych zmian w uldze B+R w latach 2016-2018

\begin{tabular}{|c|c|c|c|}
\hline \multicolumn{4}{|c|}{ Ulga na działalność badawczo-rozwojową } \\
\hline Stan prawny & 2016 & 2017 & 2018 \\
\hline $\begin{array}{l}\text { Uzależnienie } \\
\text { intensywności preferencji } \\
\text { podatkowej od wielkości } \\
\text { przedsiębiorstwa }\end{array}$ & tak & tak & nie \\
\hline $\begin{array}{l}\text { Limit odliczenia kosztów } \\
\text { kwalifikowanych }\end{array}$ & $\begin{array}{l}\text { Wynagrodzenia - } \\
30 \% \\
\text { Pozostałe koszty } \\
\text { kwalifikowane : } \\
-20 \% \text { sektor MŚP } \\
-10 \% \text { pozostali }\end{array}$ & $\begin{array}{l}\text { Wynagrodzenia - } \\
50 \% \\
\text { Pozostałe koszty } \\
\text { kwalifikowane: } \\
-50 \% \text { - sektor MŚP } \\
-30 \% \text { tych kosztów }\end{array}$ & $\begin{array}{l}\text { - } 150 \% \text { - centrum } \\
\text { badawczo-rozwojowe } \\
\text { - 100\% - pozostałe } \\
\text { przedsiębiorstwa }\end{array}$ \\
\hline $\begin{array}{l}\text { Okres, w którym można } \\
\text { rozliczyć ulgę }\end{array}$ & $\begin{array}{l}\text { kolejne } 3 \text { lata } \\
\text { podatkowe }\end{array}$ & $\begin{array}{l}\text { wydłużenie do } \\
6 \text { kolejnych lat } \\
\text { podatkowych }\end{array}$ & $\begin{array}{l}6 \text { kolejnych lat } \\
\text { podatkowych }\end{array}$ \\
\hline $\begin{array}{l}\text { Możliwość skorzystania } \\
\text { przez przedsiębiorstwa } \\
\text { z SSE }\end{array}$ & nie & nie & tak \\
\hline $\begin{array}{l}\text { Rozszerzenie katalogu } \\
\text { kosztów kwalifikowanych }\end{array}$ & - & - & tak \\
\hline
\end{tabular}

Źródło: opracowanie własne na podstawie porównania stanów prawnych ustawy u.p.d.o.f. oraz u.p.d.o.p. za lata 2016-2018.

Kolejną istotną zmianą dla podatników jest wydłużenie okresu rozliczenia ulgi podatkowej w 2017 r. do 6 kolejnych lat podatkowych z 3 lat podatkowych w 2016 r. W 2018 r. nie dokonano zmian w tym obszarze. Bezsprzecznie za korzystną zmianę dla przedsiębiorców należy uznać możliwość skorzystania z ulgi B+R przez podmioty prowadzące działalność na terenie specjalnej strefy ekonomicznej w zakresie dochodów pozastrefowych.

\section{PODSUMOWANIE}

Polskie przedsiębiorstwa zajmuja od lat niskie pozycje na tle innych krajów UE w zakresie innowacyjności. Pozycja Polski w rankingach UE nie poprawiła się istotnie w ostatnich latach. Pozytywną przesłankę poprawy tej sy- 
tuacji stanowi natomiast wzrostowa tendencja wielkości wskaźników, takich jak Sumaryczny Indeks Innowacyjności oraz wysokość nakładów na działalność badawczo-rozwojowa.

Konieczna jest zmiana dotychczasowego modelu wsparcia działalności innowacyjnej opartego na pozyskiwaniu funduszy UE na model oparty na innych rozwiąaniach, np. narzędzia w formie preferencji podatkowych. Najpopularniejszym narzędziem wprowadzonym ostatnio jest ulga $B+R$.

Ulga $\mathrm{B}+\mathrm{R}$ posiada cechy narzędzia wspierającego działalność innowacyjna w zakresie podejmowania i prowadzenia działalności badawczo-rozwojowej przez polskich przedsiębiorców. Cech tych nie spełniała poprzednia forma preferencji podatkowych w postaci ulgi na nabycie nowych technologii, której istotą była sama czynność nabycia nowej technologii, a nie podejmowanie jakichkolwiek inicjatyw rozwojowych, które mogły przyczynić się do wzrostu innowacyjności polskich przedsiębiorstw. W stosunku do ówczesnej ulgi ulga na działalność badawczo-rozwojową nie posiada restrykcyjnych warunków determinujących prawo do skorzystania z preferencji podatkowej. Również wymiar korzyści wynikających z ulgi B+R jest dla podatników znacznie atrakcyjniejszy.

Modyfikacje ulgi B+R w latach 2017 i 2018 należy uznać za pozytywne zarówno dla podatników, jak i samego spełnienia przez ulgę funkcji wsparcia działalności $\mathrm{B}+\mathrm{R}$, ponieważ modyfikacja mechanizmu ulgi została dostosowana do potrzeb wsparcia podatników.

Konkludujac, ulga B+R spełnia kryteria narzędzia proinnowacyjnego wsparcia przedsiębiorstw i z prawdopodobieństwem na wysokim poziomie można wnioskować o intensywnym stopniu wykorzystania tego narzędzia przez przedsiębiorców w kolejnych latach. Niemniej w celu poprawy pozycji innowacyjności przedsiębiorstw niezbędne są prace nad wdrażaniem innych rozwiązań proinnowacyjnych. Ulga B+R może stanowić jedynie wsparcie/uzupełnienie innych narzędzi. Indywidualnie jednak nie wpłynie na wzrost pozycji innowacyjnej polskich przedsiębiorstw.

mgr Katarzyna Łukaszewska

Uniwersytet Ekonomiczny w Poznaniu

katarzyna.lukaszewska@phd.ue.poznan.pl

\section{THE TAX RELIEF FOR RESEARCH AND DEVELOPMENT AS AN OPPORTUNITY TO IMPROVE THE INNOVATION POSITION OF POLISH ENTERPRISES}

Sum mary

The aim of the article is to present the potential of the R\&D relief as a support and activator prompting Polish entrepreneurs to take measures that may help Polish enterprises to increase their innovation position. The original form of the relief in question and its subsequent modifications have been examined. The research was conducted on the basis of a comparative analysis and a case analysis, using the deduction and induction methods. Since the innovativeness of Polish enterprises, measured by the Summary Innovation Index, had for years been at one of the lowest levels recorded in the European Union, the R\&D allowance was introduced 
into the Polish tax system with an aim of improving the position of Polish enterprises in innovation ratings. The analysis of the mechanism, the criteria and the scope of potential deductions under the relief allows to state that it is a much more advantageous and effective tool providing more benefits to entrepreneurs than the former allowance offered for the purchase of new technologies. The results of the conducted analysis allow a conclusion that enterprises are highly interested in using the relief which is an effective, albeit not a direct instrument supporting innovation activity. 
